\title{
Improvement of Insecticidal Efficacy of Carbaryl Emulsifiable Concentrates by Isobornyl Thiocyanoacetate*
}

\author{
B. S. Parmar and N. P. Agnihotri \\ Division of Agricultural Chemicals, Indian Agricultural Research Institute, \\ New Delhi-110012, India
}

(Received September 1, 1983)

\begin{abstract}
An emulsifiable concentrate of carbaryl was developed and its efficacy improved by synergization with isobornyl thiocyanoacetate. The formulations exhibited satisfactory physico-chemical characteristics. Emulsions (up to $0.2 \%$ carbaryl) from these concentrates exhibited no phytotoxicity against Vicia faba, Daucus carrota, Brassica oleracea, Gossypium hirsutum, Raphanus sativus, Brassica juncea and Lycopersicum esculentum. The synergized concentrate, however, showed phytotoxicity against Solanum tuberosum and Hibiscus esculentus. Isobornyl thiocyanoacetate showed a factor of synergism of 2.5 at the $1: 1$ synergized concentrate. For a comparable bioefficacy with the commercial WDP, only $1 / 3$ to $1 / 5$ of carbaryl from these concentrates was required. Their $0.05 \%$ emulsions controlled the bollworm complex in cotton, increased seed cotton yield and left no detectable residues in lint and seed at harvest. In insect control and yield increase, the $0.05 \%$ emulsions from the synergized EC matched $0.2 \%$ carbaryl from WDP and $0.02 \%$ fenvalerate emulsions. Carbaryl WDP and fenvalerate, however, left detectable residues at harvest.
\end{abstract}

Carbaryl (1-naphthyl $N$-methyl carbamate) is one of the earliest and most popular amongst carbamate pesticides. Its low mammalian toxicity, environmental degradability and a broad spectrum of insect toxicity are responsible for its extensive usage throughout the world. A number of its solid and liquid formulations are commercially available and these could be referred to in literatures. No information on an emulsifiable concentrate (EC) formulation of this toxicant was traceable in literatures although such formulations are stated to be in use in Japan (personal communication). This paper embodies the results of emulsifiable concentrates of carbaryl developed by us. The efficacy of carbaryl in such concentrates has been improved by using isobornyl thiocyanoacetate as a synergist.

* Contribution No. 201-2 from the Division of Agricultural Chemicals.

\section{MATERIALS AND METHODS}

\section{Materials}

Technical carbaryl $(97 \%$ a.i. $)$ and $50 \%$ commercial carbaryl (Sevin) water dispersible powder were obtained from M/s Union Carbide (India) Ltd., Bhopal, Madhya Pradesh, India. Fenvalerate (Sumicidin 20\% EC) was obtained from $\mathrm{M} / \mathrm{s}$ Rallis India Ltd., Bangalore, Karnataka, India. Isobornyl thiocyanoacetate was procured from $\mathrm{M} / \mathrm{s}$ Camphor and Allied products Ltd., Bareily, Uttar Pradesh, India. Various solvents, surfactants and other auxiliaries were commercial grade, indigenously available materials.

\section{Preparation of Emulsifiable Concentrates and Determination of Physico-chemical Characteristics}

The concentrates (carbaryl 10\% w/v) were prepared as per method reported earlier. ${ }^{1)}$ 
The synergized concentrate contained the insecticide and isobornyl thiocyanoacetate (synergist), at $1: 1$. Emulsion characteristics, cold test (low temperature stability) and acidity or alkalinity were evaluated before as well as after heat stability requirement; flash point and visual description were noted only before the heat stability requirement. Recommended ISI $^{2)}$ test methods were followed. More severe test conditions compared to those prescribed $^{2)}$ were also investigated and these are appropriately indicated in the text.

\section{Phytotoxicity}

Different carbaryl concentrations from both the normal and the synergized concentrates were sprayed as emulsions over bean (Vicia $f a b a)$ at flowering and pod formation, over carrot (Daucus carrota) at full carrot formation, over cauliflower (Brassica oleracea) at flowering, over cotton (Gossypium hirsutum) 11-17 days old in pots and 7 week old in the field, over okra (Hibiscus esculentus) 15 days old, over potato (Solanum tuberosum) at tuber formation, over raddish (Raphanus sativus) at full raddish formation, over rapeseed (Brassica juncea) at flowering and pod formation and over tomato (Lycopersicum esculentum) at flowering. Solvent emulsions at 2 and $5 \%$ were sprayed as controls. The plants were generally oversprayed by completely drenching them with the spray. Only visual observations indicating any adverse effect on the plants were recorded. Observation period ranged between 10-40 days.

\section{Bioassay}

Isobornyl thiocyanoacetate was evaluated as a carbaryl synergist (carbaryl : synergist, $1: 5$ ) initially by the filter paper impregnation technique $^{3)}$ and subsequently in the emulsifiable concentrates (carbaryl : synergist, $1: 1$ ) by the Potter's direct spray technique.4) Acetone solutions $(0.5 \mathrm{ml})$ of carbaryl and/or synergist were impregnated on pieces of filter paper (dia $7 \mathrm{~cm}$ ) without using any fixative oil. After placing the ground glass rings, 10 insects per paper were released in 3 replications. Spraying details by the Potter's technique are already reported. ${ }^{5)}$ A comparison of these concentrates with the commercial $50 \%$ carbaryl water dispersible powder (WDP) was also done by the spray technique. ${ }^{4)}$ Appropriate untreated, solvent, solvent water emulsions, etc. controls were maintained as required. Laboratory reared, 15 days old adult red flour beetle, Tribolium castaneum Herbst. was the test insect. The mortality counts, recorded $72 \mathrm{hr}$ after the treatment were subjected to probit analysis ${ }^{6)}$ and factor of synergism ${ }^{7)}$ or carbaryl units for the same bioefficacy worked out.

\section{Field Experiment}

Cotton, Gossypium hirsutum Linn. "Selection 95" was sown in $10 \mathrm{~m}^{2}$ plots on 25th May, 1980 on the farm of the Institute. A randomized block design was employed and each treatment was replicated four times. Five sprays each of carbaryl WDP $(0.2 \%$ suspension), carbaryl and synergized carbaryl EC $(0.05 \%$ emulsion each) and fenvalerate EC $(0.02 \%$ emulsion) were made @ $500 l /$ ha spray at 10 days interval commencing from 11th August, 1980, on the day when bollworms first appeared.

\section{Efficacy of Insecticidal Treatments}

Starting with the 2nd spray, 8 plants per plot were randomly selected before each spray, number of healthy and affected bolls were counted and infestation expressed as \% damage.

\section{Residue Determination}

The residues were estimated in leaves (at $1 \mathrm{hr}$ and 10th day after each spray) and lint and seed (at harvest, 20th October). Carbaryl residues were extracted with methylene chloride, filtered through Hyflo Super Cel and cleaned. ${ }^{8)}$ Carbaryl in cleaned extracts was hydrolyzed with strong alkali, derivatized with 1-fluoro-2,4-dinitrobenzene and estimated by GLC $^{9)}$ using Tracor MT 220 gas chromatograph.

Fenvalerate residues were extracted in acetone, cleaned up by passing through a neutral alumina column and analyzed by GLC. ${ }^{10,11)}$

Various GLC parameters for both insecticides were: detector ${ }^{63} \mathrm{Ni}$ electron capture; column $3 \%$ OV-17 on Chromosorb W (HP); 
temperatures $\left({ }^{\circ} \mathrm{C}\right)$-column 225, inlet 250, detector 275; carrier gas (N) $80 \mathrm{ml} / \mathrm{min}$. Three microlitre sample was injected.

\section{RESULTS AND DISCUSSION}

\section{Physico-chemical Characteristics}

The physico-chemical characteristics of the concentrates are reported in Table $1(\mathrm{a}, \mathrm{b}$ and c). As it is apparent, the formulations generally complied with the requirements prescribed for emulsifiable concentrates. To the best of informations, no specifications for a carbaryl $\mathrm{EC}$ are as yet available; leaving no scope for comparisons.

IS: 69402) prescribes conducting of the emulsion stability test at $30^{\circ} \mathrm{C}$ for $1.0 \mathrm{hr}$ whereas CIPAC $^{12)}$ prescribes a period of $24 \mathrm{hr}$ followed by re-emulsification after that period. The present samples were left at room temperature $\left(\sim 20^{\circ} \mathrm{C}\right)$ after $8 \mathrm{hr}$. As it is apparent from Table la, these formed stable emulsions and at $24 \mathrm{hr}$, little (often unmeasurable) solid settled at the bottom. Re-emulsification of the samples at $24 \mathrm{hr}$ left this solid dispersed up to the final observation period.

In India, as a normal agricultural practice, pesticide emulsions are sprayed within 1-2 hr of their preparation. The present concentrates can thus be safely recommended.

A cold test at $10^{\circ} \mathrm{C}$ for $1 \mathrm{hr}$ is the usual ISI prescription. ${ }^{2)} \mathrm{CIPAC}^{12)}$ prescribes conducting this test at $0 \pm 1{ }^{\circ} \mathrm{C}$ with occasional shaking for $1 \mathrm{hr}$ and subsequently keeping and observing the samples for 7 days at this temperature. In these studies, the conditions as stated in Table $1 \mathrm{~b}$ were maintained. Under these, the test samples performed satisfactorily. Slight solid settling, whenever observed, vanished when the samples were brought back to above $20^{\circ} \mathrm{C}$.

The flash point of both the formulations was above $24.5^{\circ} \mathrm{C}$ and acidity as $\mathrm{H}_{2} \mathrm{SO}_{4}$, though marginally above the usually prescribed limit of $0.05 \%$, was not expected to have any adverse effect on this active ingredient.

\section{Phytotoxicity}

The $0.1 \%$ carbaryl emulsions prepared from any one of these concentrates showed no phytotoxicity against any test plant except

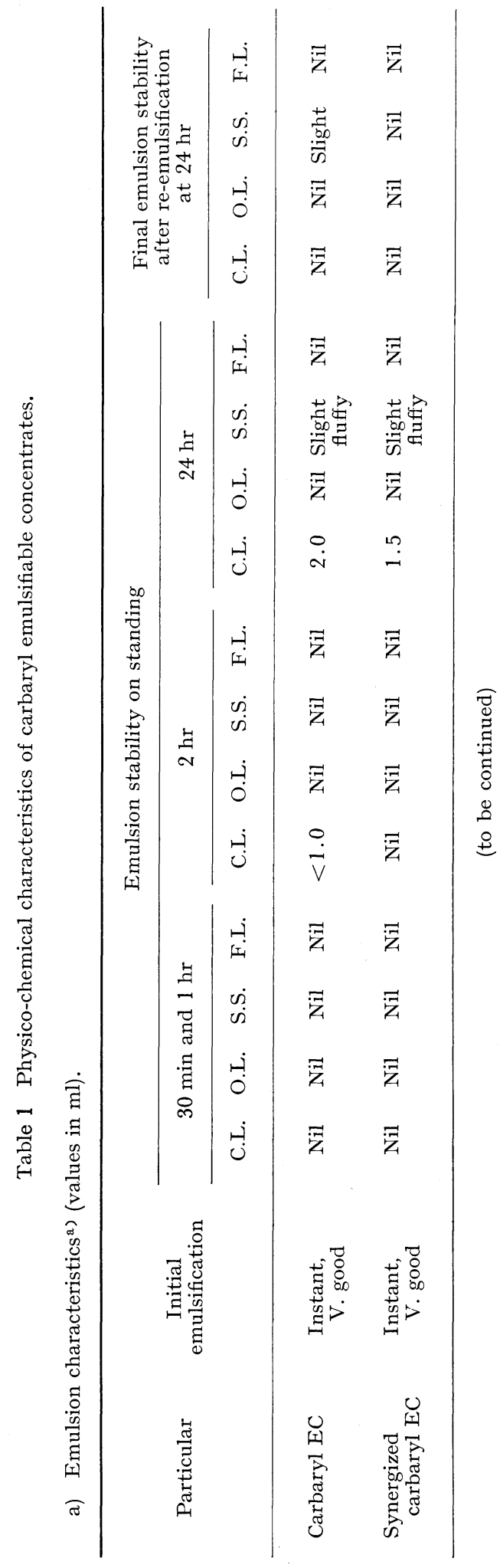


Table 1 (continued)

b) Cold test ${ }^{\text {b) }}$ (low temperature stability).

\begin{tabular}{|c|c|c|c|c|c|c|c|c|c|c|}
\hline \multirow{2}{*}{ Particular } & \multicolumn{5}{|c|}{ Pre-heat storage test } & \multicolumn{5}{|c|}{ Post-heat storage test } \\
\hline & $\begin{array}{c}\text { Temp. } \\
\left({ }^{\circ} \mathrm{C}\right)\end{array}$ & $\begin{array}{l}\text { Period } \\
\text { (upto) }\end{array}$ & O.M. & Turb. & S.S. & $\begin{array}{c}\text { Temp. } \\
\left({ }^{\circ} \mathrm{C}\right)\end{array}$ & $\begin{array}{l}\text { Period } \\
\text { (upto) }\end{array}$ & O.M. & Turb. & S.S. \\
\hline \multirow[t]{4}{*}{ Carbaryl EC } & $0-1$ & $2 \mathrm{hr}$ & Nil & Nil & Nil & 10 & $7 \mathrm{hr}$ & Nil & Nil & Nil \\
\hline & 3 & $6 \mathrm{hr}$ & Nil & Nil & Nil & 6 & $96 \mathrm{hr}$ & Nil & Nil & Nil \\
\hline & 6 & $24 \mathrm{hr}$ & Nil & Nil & Nil & & & & & \\
\hline & 7 & 25 days & Nil & Nil & Nil & & & & & \\
\hline \multirow{5}{*}{$\begin{array}{l}\text { Synergized } \\
\text { carbaryl EC }\end{array}$} & $0-1$ & $2 \mathrm{hr}$ & Nil & Nil & Nil & 10 & $7 \mathrm{hr}$ & Nil & Nil & Nil \\
\hline & 3 & $6 \mathrm{hr}$ & Nil & Nil & Nil & 6 & $24 \mathrm{hr}$ & Nil & Nil & Nil \\
\hline & 7 & $24 \mathrm{hr}$ & Nil & Nil & Nil & & $55 \mathrm{hr}$ & Nil & Nil & Slight \\
\hline & & $48 \mathrm{hr}$ & Nil & Nil & Slight & & 11 days & Nil & Nil & Slight \\
\hline & & 25 days & Nil & $\begin{array}{l}\mathrm{Nil} \\
\quad \text { (n } \\
\text { inc }\end{array}$ & $\begin{array}{l}\text { Slight } \\
\text { further } \\
\text { rease) }\end{array}$ & & & & \multicolumn{2}{|c|}{$\begin{array}{l}\text { (no further } \\
\text { increase) }\end{array}$} \\
\hline
\end{tabular}

c) Acidity, flash point and general description.

\begin{tabular}{|c|c|c|c|c|}
\hline \multirow{2}{*}{ Particular } & \multicolumn{2}{|c|}{ Acidity $(\%)$ as $\mathrm{H}_{2} \mathrm{SO}_{4}(\mathrm{w} / \mathrm{w})$} & \multirow{2}{*}{$\begin{array}{c}\text { Flash point } \\
\left({ }^{\circ} \mathrm{C}\right)\end{array}$} & \multirow{2}{*}{ Description } \\
\hline & $\begin{array}{l}\text { Pre-heat } \\
\text { storage }\end{array}$ & $\begin{array}{l}\text { Post-heat } \\
\text { storage }\end{array}$ & & \\
\hline Carbaryl EC & 0.056 & 0.064 & 49.5 & $\begin{array}{l}\text { Clear stable liquid, deep yellow colour } \\
\text { free from extraneous impurities }\end{array}$ \\
\hline $\begin{array}{l}\text { Synergized } \\
\text { carbaryl EC }\end{array}$ & 0.056 & 0.070 & 51.0 & $\begin{array}{l}\text { Clear stable liquid, brown colour free } \\
\text { from extraneous impurities }\end{array}$ \\
\hline
\end{tabular}

a) C.L.: creamed layer at top, O.L.: free oil separation layer, S.S. : solid settled, F.L.: froth layer at top. The values after the heat stability test were the same as before the test except a change in $2 \mathrm{hr}$ creamed layer value from $<1.0$ to nil.

b) O.M.: oily matter, Turb.: turbidity, S.S.: solid separation.

potato (Solanum tuberosum) in which case the emulsions from the synergized EC severely damaged about $43 \%$ of the treated leaves. Cotton (Gossypium hirsutum) was in addition sprayed with 0.2 and $0.5 \%$ carbaryl emulsions. Whereas $0.2 \%$ emulsions caused no phytotoxicity, the $0.5 \%$ concentrations from both the concentrates were phytotoxic. Increasing synergist concentration in the emulsions increased phytotoxic effect. The solvent and surfactant had no effect. The $0.2 \%$ carbaryl emulsions from the synergized EC were phytotoxic against okra (Hibiscus esculentus) too.

\section{Synergization by Isobornyl Thiocyanoacetate} The factors of synergism by using isobornyl thiocyanoacetate as a carbaryl synergist are reported in Table 2. Whereas the preliminary screening of isobornyl thiocyanoacetate as a carbaryl synergist (carbaryl : synergist, $1: 5$ ) by applying acetone solutions on filter papers revealed a factor of 31.4 , the same in the $1: 1$ synergized EC by the direct spray technique was 2.5. A higher factor by the filter paper impregnation technique was expected because no fixative oil as prescribed $i^{3)}$ was used. This screening had a limited objective of confirming the synergistic ability of isobornyl thiocyanoacetate before its incorporation into the EC. The factor obtained by testing the concentrates by the direct spray technique provided an index for the probable potential of the synergist in the final formulation. 
4. Comparison with the Commercial Carbaryl Water Dispersible Powder

The data in Table 3 reveal that for the same bioefficacy by Potter's direct spray technique, 1 unit of carbaryl from its WDP, 0.368 unit from EC and 0.219 unit from the synergized EC were required. It implied that as compared to the use of a WDP, only about $1 / 3$ to $1 / 5$ of carbaryl from these concentrates was required, resulting in a considerable economy in the use of this insecticide on one hand and a pollution free environment on the other. This finding has been verified on a field scale against cotton.

It may be mentioned that the reason for the differences in the $\mathrm{LC}_{50}$ values of carbaryl emulsions in Tables 2 and 3 by the Potter's direct spray technique was that these bioassay experiments were conducted under ambient conditions during two different seasons of the year-namely summer (Table 2, Temp. $\sim 35^{\circ} \mathrm{C}$, R.H. $\sim 40 \%$ ) and rainy summer (Table 3, Temp. $\sim 35^{\circ}$ C, R.H. $\sim 95 \%$ ). The environment influenced the actual volume of the spray reaching petri-dishes.

\section{Field Evaluation against Cotton \\ 5.1 Bollworms control}

Data in Table 4 reveal that all the treatments were effective in controlling cotton bollworms. Fenvalerate was most effective followed by the synergized carbaryl EC, carbaryl WDP and carbaryl EC respectively. Fenvalerate, carbaryl-synergized EC and WDP were statistically at par at 5\% level. These were better than carbaryl EC.

It is apparent that both the carbaryl emulsifiable concentrates, despite their lower rate of application, were effective in controlling bollworms. Performance of the $0.05 \%$ synergized EC matched with $0.02 \%$ fenvalerate and $0.2 \%$ carbaryl WDP treatments. Carbaryl $\mathrm{EC}$, though not as effective as these three treatments, gave a significant control of bollworms; the differences being significant even at $1 \% \mathrm{CD}$ level $\mathrm{A}$ slightly higher dose of carbaryl from this EC may be required for a parallel performance.

\subsection{Seed cotton yield}

Concomitant with the reduced bollworm damage, the yield increased in all the treatments. Highest yield was with fenvalerate, 
Table 3 Comparative performance of the emulsifiable concentrates with the commercial carbaryl water dispersible powder.

\begin{tabular}{llll}
\hline \multicolumn{1}{c}{ Particular } & \multicolumn{1}{c}{ WDP } & \multicolumn{1}{c}{ EC } & \multicolumn{1}{c}{ Synergized EC } \\
\hline Heterogeneity & $\chi^{2}{ }_{(5)=5.617}$ & $\chi^{2}{ }_{(5)}=2.301$ & $\chi^{2}{ }_{(4)}=4.035$ \\
Regression equation & $Y=0.839 x+2.633$ & $Y=0.922 x+3.721$ & $Y=1.975 x+0.732$ \\
Log $\left(\mathrm{LC}_{50} \times\right)^{\mathrm{a})} \pm \mathrm{SE}$ & $2.8210 \pm 0.3116$ & $1.3872 \pm 0.3822$ & $2.1610 \pm 0.1098$ \\
$\mathrm{LC}_{50}(\%$ carbaryl $)$ & 0.0662 & 0.0244 & 0.0145 \\
Fiducial limits & $0.0323-0.1357$ & $0.0101-0.0588$ & $0.0113-0.0187$ \\
Relative carbaryl units & 1.000 & 0.368 & 0.219 \\
\hline
\end{tabular}

a) $\times 10^{3}$ for $\mathrm{EC}, \times 10^{4}$ for synergized EC and WDP.

Table 4 Relative efficacy of carbaryl and fenvalerate formulations against cotton bollworm complex.

\begin{tabular}{|c|c|c|c|c|c|}
\hline \multirow{2}{*}{ Treatment } & \multicolumn{4}{|c|}{$\begin{array}{c}\text { Bollworm infestation (\%) } \\
\text { observations }\end{array}$} & \multirow{2}{*}{$\begin{array}{c}\text { Seed cotton } \\
\text { yield } \\
(\mathrm{kg} / \mathrm{ha})\end{array}$} \\
\hline & $\mathrm{I}$ & II & III & IV & \\
\hline Carbaryl EC & 14.97 & 19.61 & 21.45 & 27.26 & 907.0 \\
\hline Synergised carbaryl EC & 12.76 & 16.46 & 19.15 & 22.37 & 1169.1 \\
\hline Carbaryl WDP & 13.73 & 18.91 & 20.03 & 21.33 & 1135.8 \\
\hline Fenvalerate EC & 9.59 & 13.11 & 16.37 & 21.12 & 1267.5 \\
\hline Control & 22.08 & 23.99 & 28.47 & 37.69 & 691.3 \\
\hline $\operatorname{Sem} \pm$ & 1.56 & 1.14 & 0.67 & 1.41 & 52.43 \\
\hline $\mathrm{CD}(5 \%)$ & 5.10 & 3.71 & 2.19 & 4.59 & 161.54 \\
\hline $\operatorname{CD}(1 \%)$ & 7.41 & 3.79 & 3.19 & 6.58 & 226.48 \\
\hline
\end{tabular}

As to I, II, III, and IV, the treatment was commenced from 11 th August, 1980 at 10 days interval, and the observations were done 10 days after the treatment.

Table 5 Residues of carbaryl and fenvalerate on cotton (Gossypium hirsutum).

\begin{tabular}{|c|c|c|c|c|c|}
\hline \multirow[b]{2}{*}{ Spray } & \multirow[b]{2}{*}{ Days } & \multicolumn{4}{|c|}{ Residues in leaves (ppm) } \\
\hline & & $\begin{array}{c}\text { Carbaryl } \\
\text { EC }\end{array}$ & $\begin{array}{l}\text { Synergised } \\
\text { carbaryl EC }\end{array}$ & $\begin{array}{l}\text { Carbaryl } \\
\text { WDP }\end{array}$ & $\begin{array}{c}\text { Fenvalerate } \\
\text { EC }\end{array}$ \\
\hline \multirow[t]{2}{*}{$I^{\text {a) }}$} & 0 & 4.60 & 6.87 & 15.24 & 7.28 \\
\hline & 10 & 1.92 & 1.86 & 1.64 & 1.22 \\
\hline \multirow[t]{2}{*}{ II } & 0 & 8.42 & 6.22 & 16.80 & 6.32 \\
\hline & 10 & 1.70 & 0.68 & 0.55 & 1.32 \\
\hline \multirow[t]{2}{*}{ III } & 0 & 3.24 & 3.27 & 17.10 & 8.26 \\
\hline & 10 & 0.23 & 0.78 & 0.77 & 1.22 \\
\hline \multirow[t]{2}{*}{ IV } & 0 & 4.50 & 6.00 & 27.20 & 6.80 \\
\hline & 10 & 0.62 & 0.96 & 6.62 & 1.40 \\
\hline \multirow[t]{2}{*}{$\mathrm{V}$} & 0 & 6.68 & 6.54 & 31.40 & 7.34 \\
\hline & 10 & 0.72 & 0.81 & 4.32 & 1.44 \\
\hline \multicolumn{2}{|c|}{ Lint at harvest } & $\mathrm{ND}^{\mathrm{b}}$ ) & ND & 0.164 & 0.085 \\
\hline \multicolumn{2}{|c|}{ Seed at harvest } & $\mathrm{ND}$ & ND & 0.147 & 0.037 \\
\hline
\end{tabular}

a) Spray I was done on 11th August, 1980. Sprays II, III, IV and V followed at 10 days interval each.

b) ND: less than $0.01 \mathrm{ppm}$. 
followed by synergized carbaryl EC, carbaryl WDP and carbaryl EC. The former three treatments were statistically at par and were better than carbaryl EC.

\subsection{Insecticide residue}

The deposits of different sprays were generally in the order of their sprayed concentrations (Table 5). The rate of insecticide dissipation by using different carbaryl formulations appeared to be the same; in 10 days, 58.2$96.7 \%$ of the applied insecticide being lost.

Fenvalerate deposits, despite its lower rate of application, were either comparable to or higher than those from carbaryl EC formulations. It could be ascribed to some inherent property of fenvalerate or to the nature of the formulation auxiliaries. The dissipation rate of fenvalerate was similar to carbaryl.

As is apparent from Table 5, at harvest no detectable residues $(<0.01 \mathrm{ppm})$ of carbaryl existed from either of two emulsifiable concentrates in both lint as well as seed. The WDP left 0.164 and $0.147 \mathrm{ppm}$ and fenvalerate 0.085 and $0.037 \mathrm{ppm}$ residues in lint and seed respectively. The carbaryl emulsifiable concentrates as such, appeared better than both the carbaryl WDP as well as fenvalerate.

\section{ACKNOWLEDGEMENTS}

The authors acknowledge the help received from Dr. K. P. Srivastava, Scientist and Mr. Shiv Dutta and Mr. A. K. Gupta, Technical Assistants.

\section{REFERENCES}

1) B. S. Parmar \& Shiv Dutta: Patent application submitted on August 5, 1981 to Indian Council of Agricultural Research for patenting.
2) I. S. I.: Methods of tests for pesticides and their formulations, IS: 6940 (1973)

3) F. A. O.: FAO Plant Prot. Bull. 18, 107 (1970)

4) C. Potter: Ann. Appl. Biol. 28, 142 (1941)

5) D. K. Sarkar \& B. S. Parmar: Agric. Biol. Chem. 43, 2291 (1979)

6) D. J. Finney: "Probit Analysis," 3rd Ed., Cambridge Univ. Press, p. 318, 1971

7) P. R. Chadwick: Pyvethrum Post 7, 25 (1963)

8) W. R. Benson \& J. M. Finnochiro: J. Assoc. Off. Agric. Chem. 48, 696 (1965)

9) E. R. Holden: J. Assoc. Off. Anal. Chem. 5, 713 (1973)

10) H. K. Jain, N. P. Agnihotri \& K. P. Srivastava: J. Entomol. Res. 3, 212 (1979)

11) H. K. Jain, N. P. Agnihotri \& K. P. Srivastava: J. Entomol. Res. 4, 161 (1980)

12) C.I.P.A.C.: “CIPAC Handbook," Vol. I, pp. $910,930(1970)$

要約

\section{Isobornyl thiocyanoacetate によるカルバリル 乳剤の殺虫効果の改良}

B. S. Parmar, N. P. Agnihotri

Isobornyl thiocyanoacetate を共力剤としてカルバリ ル乳剂の改良を試みたところ, 両者 $1: 1$ の組成で殺虫 効果に括いて 2.5 倍の共力効果が得られた. この共力剂 を加えた乳剤は，バレイショおよびオクラに対して薬害 を生じた。圑場試験の結果は，この改良剤の有効成分で $0.05 \%$ の乳濁液が市販の水和剂の $0.2 \%$ (成分) 懸濁液 および $0.02 \%$ フェンバレレート乳濁液に相当する殺虫 効果と収量増のあることを示している。 また，収穫時に おいてカルバリル水和剤およびフェンバレレート乳剤散 布区で各薬剂の残留が認められるのに，カルバリル乳剂 では検知できなかった (<0.01 ppm). 